\title{
PRESCRIBING PATTERNS OF METHYLPHENIDATE IN A SOUTH AFRICAN PATIENT POPULATION WHO ARE MEMBERS OF A PRIVATE MEDICAL AID
}

\section{Ilse Truter}

DCom, BPharm, MSc, PhD

Registered Pharmacist, Associate Professor in Pharmacy and Head of Pharmacy Practice

Department of Pharmacy, Nelson Mandela Metropolitan University

Corresponding author: ilse.truter@nmmu.ac.za

\section{Theunis $\mathbf{J}$ van $\mathbf{W}$ Kotze}

DSc

Director, TheoData cc

Keywords: Attention Deficit Hyperactivity Disorder (ADHD); Methylphenidate; drug utilisation; prescribing patterns; prescribed daily dose (PDD)

\begin{abstract}
Methylphenidate is primarily used for attention deficit hyperactivity disorder (ADHD) in children. The primary aim of the study was to investigate the prescribing patterns of methylphenidate of a medical aid patient population in a private sector and to compare the results with previous studies. An exposure cohort drug utilisation study was conducted. Data were obtained from a South African medical aid administrator. Prescription records for 115 patients who received methylphenidate during 2002 were retrospectively analysed. Nearly three-quarters (73.0\%) of the patients were males and $79.1 \%$ of patients were 18 years or younger. The average age of patients was $15.6(S D=10.8)$ years. Seventeen patients were 30 years or older. Two-thirds of prescriptions (67.3\%) were for methylphenidate $10 \mathrm{mg}$ (the innovator product), $20.7 \%$ were for the $20 \mathrm{mg}$ slow-release innovator product and the rest were prescriptions for the recently introduced $10 \mathrm{mg}$ generic equivalent tablet. Patients received on average $4.0(S D=3.3)$ prescriptions for methylphenidate during the year. The average Prescribed Daily Dose (PDD) for methylphenidate was $15.4(S D=7.6) \mathrm{mg}$. Further studies are recommended, especially into the quality of life of patients before and after receiving methylphenidate. The impact of methylphenidate on the academic performance of patients should also be quantified.
\end{abstract}

\section{OPSOMMING}

Metielfenidaat word hoofsaaklik vir aandag-gebrek-hiperaktiwiteitsindroom in kinders gebruik. Die primêre doel van die studie was om die voorskryfpatrone van metielfenidaat van 'n mediese hulpfonds-pasiëntpopulasie in ' $n$ privaatsektor te ondersoek en om die resultate met dié van vorige studies te vergelyk. 'n Studie oor die gebruik van geneesmiddels is uitgevoer. Data is van 'n Suid-Afrikaanse mediese hulpfonds-administreerder verkry. Rekords van voorskrifte vir 2002 van 115 pasiënte wat metielfenidaat ontvang het, is retrospektief ontleed. Bykans ' $n$ driekwart (73.0\%) van die pasiënte was mans en $79.1 \%$ van die pasiënte was 18 jaar of jonger. Die gemiddelde ouderdom van die pasiënte was 15.6 (SD=10.8) jaar. Sewentien pasiënte was 30 jaar of ouer. Twee-derdes van die voorskrifte (67.3\%) was vir metielfenidaat $10 \mathrm{mg}$ (die innoveerderproduk), $20.7 \%$ was vir die $20 \mathrm{mg}$ stadig-vrystellende innoveerderproduk en die res was voorskrifte vir die $10 \mathrm{mg}$ generiese ekwivalent wat onlangs bekend gestel is. Pasiënte het gemiddeld 4.0 (SD=3.3) voorskrifte vir metielfenidaat gedurende die jaar ontvang. Die gemiddelde Voorgeskrewe Daaglikse Dosis (VDD) vir metielfeniaat was 15.4 (SD=7.6) mg. Verdere studies word aanbeveel, veral met betrekking tot die lewenskwaliteit van pasiënte vóór en nadat hulle metielfenidaat gebruik het. Die impak van metielfenidaat op die akademiese prestasie van pasiënte behoort ook gekwantifiseer te word. 


\section{INTRODUCTION}

Methylphenidate (N06B A04) is primarily used in South Africa for narcolepsy and attention deficit hyperactivity disorder (ADHD) in children (SAMF, 2003:449). According to the British National Formulary (BNF, 2003:198) methylphenidate is indicated as part of a comprehensive treatment programme for ADHD when remedial measures alone prove insufficient (the BNF therefore does not mention narcolepsy as an indication for methylphenidate). ADHD is a common yet controversial syndrome of unknown aetiology characterised by varying degrees of inappropriate hyperactivity, impulsivity and inattention (Markowitz \& DeVane, 2000:4). International studies have yielded ADHD prevalence rates of between $1.7 \%$ and $16 \%$, dependent on the population assessed and the criteria applied (Goldman, Genel, Bezman \& Slanetz, 1998:1102; Markowitz \& DeVane, 2000:5). Epidemiologic studies using standardised diagnostic criteria suggest that $3 \%$ to $6 \%$ of the schoolaged population may have ADHD (Goldman et al. 1998:1100). Some studies have suggested a somewhat lower prevalence, but others, particularly those using newer, broader criteria, yield prevalence rates well above 6\% (Goldman et al. 1998:1106). These studies have been conducted in a number of different countries and encompass a range of racial and socio-economic backgrounds in the populations examined (Goldman et al. 1998:1106).

There are more boys with diagnosed ADHD than girls, with male to female ratios ranging from 4:1 to 6:1 (Berry, Shaywitz \& Shaywitz, 1985:801). Some studies suggest that ADHD is diagnosed three to nine times more often in boys than in girls (Markowitz \& DeVane, 2000:5). Various studies confirm the increasing trend for girls to receive pharmacotherapy for ADHD (Robison, Sclar, Skaer \& Galin, 1999:216) and that girls are now being diagnosed more often than in the past (Markowitz \& DeVane, 2000:5). Reasons for this gender discrepancy are not clear, but some researchers suggested selective referral bias in the past since girls may have primarily inattentive and cognitive problems and less of the aggressive/impulsive conduct symptomatology which leads to earlier referral (Cantwell, 1996:978; Baumgaertel, Wolraich \& Dietrich, 1995:629-638). It has been stated that the number of prescription orders written for females has increased disproportionately compared with that of males, and although ADHD exists in adults as well as children, the adult form affects females more often than males (Wick, 1993:52).

Although various medications have been assessed for the treatment of ADHD, the psychostimulants (methylphenidate, dextroamphetamine, mixed amphetamine salts and pemoline) remain the drugs of choice for treating ADHD (Elia, Ambrosini \& Rapoport, 1999: 780-788; Goldman et al. 1998:1103). However, their role and indications remain controversial. Stimulants have been used for almost 50 years, although the exact mechanism of action is still unknown (Wick, 1993:52). Methylphenidate, created in 1955, accounted for more than $90 \%$ of stimulant use in ADHD in the United States of America (USA) in the late 1990s (Goldman et al. 1998:1103). The National Institute for Clinical Excellence (NICE) has recommended (October 2000) that methylphenidate should be used as part of a comprehensive treatment programme for children and adolescents with a diagnosis of severe ADHD, and that treatment should be initiated by a specialist in ADHD (BNF, 2003:197). Methylphenidate also remains the mainstay for the pharmacological management of ADHD in South Africa.

Methylphenidate is a dopamine agonist and is readily absorbed orally, with a half-life of one to two hours (SAMF, 2003:449). The exact percentage of people in South Africa receiving methylphenidate is unknown. Sales figures, however, indicate that there has been a steady increase in the use of methylphenidate (Crutchley \& Temlett, 1999:1076). A survey conducted in the Pinetown municipal area of KwaZulu-Natal, South Africa, in 1991 indicated that $1.65 \%$ of all learners were on methylphenidate (Crutchley \& Temlett, 1999:1076). The ratio of boys to girls on methylphenidate was 9 to 1 , and the age at which treatment was begun ranged from two to eleven years, with an average age of 7.6 years (Crutchley \& Temlett, 1999:1076). A study conducted in North Carolina, USA, found that $15 \%$ of boys in grades 1 to 5 had received an ADHD diagnosis while $5 \%$ of girls were diagnosed with ADHD (Attention Deficit Hyperactivity Disorder, 2004:2). In addition, three times as many boys as girls take medication to treat the condition (Attention Deficit Hyperactivity Disorder, 2004:2).

The long-term safety of stimulant treatment must be considered in the treatment of ADHD. Three areas that 
are especially of concern in chronic stimulant treatment are the effects on growth, tics and cardiovascular parameters (Spencer, 2003). Firstly, the stimulant most likely to cause growth retardation is dexamphetamine (Attention Deficit Hyperactivity Disorder, 2004:16). Although growth is not generally affected by methylphenidate it remains advisable to monitor growth during treatment (BNF, 2003:197). It is especially recommended to monitor growth in children (both height and weight gain) where doses of methylphenidate exceed $30 \mathrm{mg} /$ day for prolonged periods (SAMF, 2003:450). Drug holidays over weekends and during school holidays are often used in an attempt to minimise growth suppression (Attention Deficit Hyperactivity Disorder, 2004:16). In one American study, growth deficits in height and weight were examined in 124 ADHD male children and adolescents and 109 controls using appropriate correction by age and parental height measures (Spencer, Biederman, Harding, O'Donnell, Faraone \& Wilens, 1996:1460). Small but significant differences in height ( $2.1 \mathrm{~cm}$ age-corrected) were identified between ADHD children and controls. However, height deficits were evident in early, but not late-adolescent patients with ADHD and were unrelated to the use of psychotropic medication. Until more is known, a small minority of ADHD children may have delays in growth and it is therefore advisable to monitor children on stimulants for growth (Spencer, 2003).

Secondly, the potential for developing tics is another adverse effect of concern and controversy in the treatment of ADHD with stimulants. Evidence which suggests a genetic relationship between ADHD and Tourette's syndrome complicates this issue (Attention Deficit Hyperactivity Disorder, 2004:16). Although the incidence of tics is rare, some individual patients on stimulants may experience a significant worsening of tics and health care practitioners should carefully monitor the course of stimulant-treated individuals for any persistent exacerbations of a tic disorder (Spencer, 2003).

Thirdly, short-term studies all show small, clinically insignificant changes in blood pressure and heart rate in children with ADHD (Spencer, 2003). It is recommended that the effect of stimulants on cardiovascular parameters nonetheless be monitored initially, with less frequent monitoring over time.
Furthermore, the abuse potential of stimulant medication must be considered. Stimulant medications are regarded as drugs of abuse owing to their dependenceproducing liability and concerns are therefore increasing that children and adolescents treated with stimulant medication may start abusing them and that their use may serve as a gateway to other illicit drugs (Practice parameter for the use of stimulant medications in the treatment of children, adolescents, and adults, 2002:45S). The fact that prescribed stimulants have a limited ability to induce euphoria by the oral route, as well as the fact that cocaine is mentioned 40 times more often than methylphenidate in emergency room mentions in the USA (Goldman et al. 1998), help to temper these concerns. The newer stimulant preparations (such as Concerta ${ }^{\circledR}$, which became available on the South African market in 2005) are less prone to abuse and diversion than immediate-release methylphenidate. Furthermore, no strong conclusive evidence exists correlating the long-term use of methylphenidate with the occurrence of adult drug abuse (Attention Deficit Hyperactivity Disorder, 2004:16).

Although pharmacotherapy alone is highly effective for short-term symptomatic and academic improvement in ADHD (Goldman et al. 1998:1103), it has not yet been shown to improve the long-term outcome for any domain of functioning such as classroom behaviour, learning or impulsivity. Optimal treatment of ADHD involves an individualised plan based on any co-morbidity as well as child and family preferences. This treatment generally will include pharmacotherapy along with adjunctive psychoeducation, behavioural therapy, environmental changes, and at times, supportive psychotherapy of the child, the family or both (Goldman et al. 1998:1106).

There is an increased focus in the lay and medical press in South Africa on the use of methylphenidate, which suggests that more detailed studies are needed to investigate the prescribing, and use of the drug. Limited information is available on the prescribing patterns of methylphenidate in large population samples in South Africa. Since no comprehensive database of all medicines prescribed and/or dispensed exists in South Africa, studies conducted on prescription databases can provide important information on various prescribing parameters regarding methylphenidate. The significance of this information is not only that it will enable 
role players to compare South African prescribing patterns to those of other countries, but also the fact that major social changes have occurred in South Africa in recent years. These changes may have impacted on the emotional, social and psychological aspects in the upbringing and development of children and adolescents, which may (or may not) have increased the prevalence of behavioural disorders, such as ADHD.

The primary aim of the study was therefore to investigate the prescribing patterns of methylphenidate in a private sector, medical aid patient population in South Africa by means of a drug utilisation study and to compare the results with previous studies.

\section{SUBJECTS AND METHODS}

The study can be classified as an exposure cohort drug utilisation study. Data for the study were obtained from a South African medical aid administrator serving eight different medical aid schemes throughout South Africa. Patients could be regarded as representing a crosssection of the South African population who are members or dependants of a private medical aid. Data were retrospectively analysed. The study design was descriptive in nature. The study covered a period of one year (1 January 2002 to 31 December 2002). The total database contained 766782 records, of which 595257 were prescription records. The rest of the records were for consultations and non-medicine items. Examples of non-medicine items included pregnancy tests, needles, syringes, cotton wool, dressings, glucometers and glucometer strips. Records of 24011 patients were included in the database. Of these, 6391 patients were 18 years or younger (26.6\% of all patients), and 4082 patients were 12 years or younger ( $17.0 \%$ of all patients).

All medication records for patients who received one or more prescriptions for methylphenidate during 2002 were extracted from the database. A total of 115 patients were included in the study. Each medication record consisted of the following fields: date of prescribing, trade name of drug, strength and quantity of the medication, codes to classify the prescriber and provider of the medication, a unique number to identify each patient, and the date of birth, gender and marital status of patients.

The Anatomical Therapeutic Chemical (ATC)
Classification System (2001), MIMS (2002) and the South African Medicines Formulary (SAMF, 2003) were used to identify and classify drugs into their main therapeutic groups. Data were analysed with Microsoft Access $^{\circledR}$ and Microsoft Excel ${ }^{\circledR}$. Descriptive statistics were used for the data analysis. Average Prescribed Daily Doses (PDDs) were calculated by multiplying the number of tablets dispensed by the tablet strength, assuming that each prescription was for a 30-day period. All costs in the study are indicated in South African Rand (R). One US Dollar (US \$1.00) was approximately equal to R10.44 (South African Rand) and one British Pound (£1.00) was approximately equal to R15.99 at the time of the study (on 27 June 2002).

Ethical approval was obtained for the study from the medical aid administrator as well as from the university. No patient or medical practitioner in the database could be identified or traced, since unique patient and practitioner identifiers (random numbers) were provided to the researcher in the database.

Diagnoses were only recorded for chronic prescriptions. One of the limitations of this study was therefore that diagnoses were not complete. Only $35.2 \%$ of the prescriptions for methylphenidate (160 of 455 prescriptions) were issued under the chronic benefit option of the medical aid schemes and only $33.4 \%$ of the prescriptions for methylphenidate (152 of 455) had a diagnosis included in the database. For those chronic prescriptions with a diagnosis, the most common diagnoses categories for methylphenidate prescriptions were "ADD of Childhood" and "Hyperkinetic Syndrome of Childhood" (149 of the 455 prescriptions). Three prescriptions had a diagnosis of "narcolepsy". These three prescriptions were for a female patient (age 30 years). It was therefore assumed that most of the 115 patients in the study received methylphenidate for ADHD. This was, however, an assumption and could not be verified. A further limitation was that products that were not paid for by the different medical aid schemes (for example, certain over-the-counter medication) were not captured in the database and were therefore not included in the study. It must also be noted that only patients who belonged to a private medical aid scheme in South Africa were included in this study. Only approximately $18 \%$ of the South African population belonged to a private medical aid scheme (Central Statistical Service, 1996). The rest of the patients were 
served by the state or public health sector for which no or limited data are available.

\section{RESULTS}

\section{Demographic characteristics of patients}

Nearly three-quarters (73.0\%) of the 115 patients were males and $79.1 \%$ of patients were 18 years or younger, as can be seen in Table 1. The average age of patients was 15.6 years ( $S D=10.8$ years, age range: 3 to 54 years). The average age of females was 17.2 (SD = 13.6) years, and of males $15.1(S D=9.6)$ years. No difference was observed with respect to age and gender $\left(\chi^{2}=6.55 ;\right.$ d.f. $\left.=4 ; p>0.1\right)$. Only 17 ( 6 females and 11 males) of the 115 patients were 30 years or older.

The median age of all patients was 12 years (11 years for females, and 12 years for males). The interquartile range for the age of all patients was 9 to 15 years (females 9 to 21.5 years, and males 9 to 15 years).

In a study conducted on a different South African patient population in 1996 on 96 patients who were prescribed methylphenidate, the average age of patients was 14.4 years, $88.5 \%$ of patients were under the age of 20 years and $75.0 \%$ of patients were males (Truter \& Kotze, 2000:S42-S43). In another South African study on methylphenidate prescribing patterns in 2002 (Truter, 2004:96), similar results were obtained, namely $41.5 \%$ of the 106 patients were between the ages of 10 and 19 years, the average age of patients was 14.6 years and $75.6 \%$ of patients were males.

\section{Prescribing frequency of methylphenidate}

The 115 patients received 455 prescriptions for methylphenidate during 2002. Patients therefore received on

Table 1: Age and gender distribution of patients

\begin{tabular}{|l|l|l|l|l|}
\hline \multirow{2}{*}{$\begin{array}{l}\text { AGE GROUPS } \\
\text { (in years) }\end{array}$} & \multicolumn{3}{|l|}{ PERCENTAGE $(\%)^{*}$} & \multicolumn{2}{l|}{ BOTH GENDERS } \\
\cline { 2 - 5 } & $\begin{array}{l}\text { FEMALES } \\
(\mathbf{n}=\mathbf{3 1})\end{array}$ & $\begin{array}{l}\text { MALES } \\
(\mathbf{n}=\mathbf{8 4})\end{array}$ & NUMBER & $\%$ \\
\hline$<10$ & 38.7 & 26.2 & 34 & 29.6 \\
\hline $10-19$ & 32.2 & 57.1 & 58 & 50.4 \\
\hline $20-29$ & 9.7 & 3.6 & 6 & 5.2 \\
\hline $30-39$ & 9.7 & 8.3 & 10 & 8.7 \\
\hline$\geq 40$ & 9.7 & 4.8 & 7 & 6.1 \\
\hline TOTAL & 100.0 & 100.0 & 115 & 100.0 \\
\hline
\end{tabular}

Table 2: Distribution of the number of methylphenidate prescriptions according to age and gender groups

\begin{tabular}{|l|l|l|l|l|}
\hline \multirow{2}{*}{$\begin{array}{l}\text { AGE GROUPS } \\
\text { (in years) }\end{array}$} & \multicolumn{3}{|l|}{ PERCENTAGE $(\%)$} & \multicolumn{2}{l|}{ * } & MOTH GENDERS \\
\cline { 2 - 5 } & $\begin{array}{l}\text { FEMALES } \\
(\mathbf{n}=\mathbf{1 1 7})\end{array}$ & $\begin{array}{l}\text { MALES } \\
(\mathbf{n}=\mathbf{3 3 8})\end{array}$ & NUMBER & $\%$ \\
\hline$<10$ & 44.4 & 29.0 & 150 & 33.0 \\
\hline $10-19$ & 37.6 & 65.1 & 264 & 58.0 \\
\hline $20-29$ & 2.6 & 1.2 & 7 & 1.5 \\
\hline $30-39$ & 6.0 & 3.5 & 19 & 4.2 \\
\hline$\geq 40$ & 9.4 & 1.2 & 15 & 3.3 \\
\hline TOTAL & 100.0 & 100.0 & 455 & 100.0 \\
\hline
\end{tabular}

$$
\chi_{(4)}^{2}=37.72 ; p<0.001 .
$$


average 4.0 (SD = 3.3) prescriptions for methylphenidate during the year. The prescribing frequency according to age and gender groups is given in Table 2 . Prescribing differences were observed $\left(\chi^{2}=37.72\right.$; d.f. $=4$; $p<0.001)$. More males received prescriptions for methylphenidate. Female patients received the drug at a younger age compared to male patients. Due to the higher count in Table 2, the chi-squared test had more power in this case (when compared to Table 1), showing a definite difference in the prescriptions between female and male patients.

In the 1996 study, patients between the ages of 10 and 19 years received $52.7 \%$ of all prescriptions for methylphenidate (Truter \& Kotze, 2000:S42-S43) compared to $58.0 \%$ in this study.

Most patients who were prescribed methylphenidate were single (101 of the 115 patients) and were child dependants (95 of the 115 patients). These patients received an average of 4.2 prescriptions for methylphenidate during the year. The thirteen married patients (all 29 years and older) received only on average 1.7 methylphenidate prescriptions during the year. The one divorced patient (41 years old) received seven prescriptions for methylphenidate during the year.

\section{Dosage forms and dosages of methyl- phenidate prescribed}

Two-thirds of all prescriptions (67.3\%) were for methylphenidate $10 \mathrm{mg}$ (the innovator product), $20.7 \%$ were for the $20 \mathrm{mg}$ slow-release innovator product and the rest were prescriptions for the recently introduced $10 \mathrm{mg}$ generic equivalent tablet (see Table 3 ).

The average PDD for methylphenidate was 15.4 (SD = 7.6) $\mathrm{mg}$. The average PDD for females was 15.1 (SD = 7.1) $\mathrm{mg}$ and for males $15.5(\mathrm{SD}=7.7) \mathrm{mg}$. The average PDDs for the different age and gender groups are given in Table 4.

Table 3: Dosage forms of methylphenidate prescribed

\begin{tabular}{|c|c|c|c|c|}
\hline METHYLPHENIDATE & NUMBER & PRESC & DTIONS & PERCENTAGE \\
\hline DOSAGE FORM & FEMALES & MALES & TOTAL & (\%) \\
\hline Ritalin $^{\circledR}(10 \mathrm{mg})$ tablets $(30)$ & 84 & 222 & 306 & 67.3 \\
\hline Ritalin SR $^{\circledast}(20 \mathrm{mg})$ SRT (30) & 20 & 74 & 94 & 20.6 \\
\hline $\begin{array}{l}\text { Ritaphen }^{\Theta}(10 \mathrm{mg}) \text { tablets } \\
\text { (30) }\end{array}$ & 13 & 42 & 55 & 12.1 \\
\hline TOTAL & 117 & 338 & 455 & 100.0 \\
\hline
\end{tabular}

Table 4: Average Prescribed Daily Doses (PDDs) of methylphenidate for the different age and gender groups

\begin{tabular}{|l|l|l|l|l|}
\hline \multirow{2}{*}{ AGE GROUPS (in years) } & NUMBER OF & \multicolumn{4}{l|}{ AVERAGE PDD (in $\mathbf{~ m g})$} \\
\cline { 2 - 5 } & \begin{tabular}{l} 
PATIENTS \\
\cline { 3 - 5 }
\end{tabular} & FEMALE & MALE & BOTH GENDERS \\
\hline$<10$ & 34 & 12.5 & 12.3 & 12.4 \\
\hline $10-19$ & 58 & 15.5 & 16.6 & 16.4 \\
\hline $20-29$ & 6 & 12.2 & 11.8 & 12.0 \\
\hline $30-39$ & 10 & 25.7 & 23.8 & 24.5 \\
\hline $40-49$ & 5 & 20.0 & 13.3 & 17.6 \\
\hline$\geq 50$ & 2 & 17.5 & - & 17.5 \\
\hline TOTAL & 115 & 15.1 & 15.5 & 15.4 \\
\hline
\end{tabular}


The dose of methylphenidate for children under six years of age has not been established (SAMF, 2003:450; MIMS, 2002). Four patients in this study were younger than six years. They all received methylphenidate in a dose of $10 \mathrm{mg}$ per day. Three of them only received methylphenidate once, while the other patient (a fiveyear-old boy) received eight prescriptions during the year and all on the chronic plan of the medical aid scheme. This boy was diagnosed with "Attention Deficit Disorder of Childhood".

As can be seen in Table 4, the patients over 30 years received methylphenidate in higher average PDDs than the younger patients. Most of these patients were prescribed methylphenidate $10 \mathrm{mg}$ tablets, with only three patients receiving methylphenidate slow-release tablets in dosage strength of $20 \mathrm{mg}$. The higher dose in older patients is probably directly related to their higher body weight (body weight and length were not available in the database).

\section{Other prescribing parameters of methylphenidate}

Proportionately more prescriptions (44.4\%) were dispensed during the period August 2002 to November 2002 compared to the other eight months of the study. The reason for this finding is unknown, but it is possible that since most patients were of school-going age and this period coincides with the latter part of the academic year when examinations are written, patients were prescribed methylphenidate to help them to improve their academic performance. This aspect could be further investigated in qualitative studies.
The number of prescriptions for methylphenidate per patient over the study period is depicted in Table 5. Nearly $30 \%$ of patients received six or more prescriptions for methylphenidate during the year, compared to only $11.5 \%$ in the other 2002 study (Truter, 2004) conducted on a different patient population. In this study, the median for females was 2.5 and for males 3.0. The observations in Table 5 are censored by the dataset which encompassed a year. There is a heavier tail for the males towards the larger values. The distribution of the number of prescriptions for males has a heavier tail towards the larger values than the female distribution of the number of prescriptions. The Wilcoxon Rank Sum test was performed to compare the medians of the prescriptions to females and the prescriptions to males, and was not significant.

Just over $60 \%$ of all prescriptions were prescribed as 30 tablets (that is, one tablet per day), followed by 60 tablets and 90 tablets. Approximately a third (35.2\%) of the prescriptions was approved under the chronic plan of the medical aid schemes.

Most (55.8\%) prescriptions for methylphenidate were issued by general practitioners. The rest of the prescriptions were issued by paediatricians, psychiatrists, neurologists, physicians or family practitioners.

Most prescriptions were obtained by patients from retail or community pharmacies, followed by general practitioners who dispensed medicine (dispensing doctors).

Table 5: Number of prescriptions for methylphenidate per patient over the study period

\begin{tabular}{|c|c|c|c|c|}
\hline \multirow{2}{*}{$\begin{array}{l}\text { NUMBER OF } \\
\text { PRESCRIPTIONS }\end{array}$} & \multicolumn{3}{|c|}{ NUMBER OF PATIENTS } & \multirow{2}{*}{$\begin{array}{l}\text { PERCENTAGE } \\
(\%)\end{array}$} \\
\hline & FEMALES & MALES & BOTH GENDERS & \\
\hline 1 & 9 & 24 & 33 & 28.7 \\
\hline 2 & 7 & 11 & 18 & 15.7 \\
\hline 3 & 3 & 14 & 17 & 14.8 \\
\hline 4 & 3 & 6 & 9 & 7.8 \\
\hline 5 & 0 & 5 & 5 & 4.3 \\
\hline$\geq 6$ & 9 & 24 & 33 & 28.7 \\
\hline TOTAL & 31 & 84 & 115 & 100.0 \\
\hline
\end{tabular}


The other medicine categories prescribed to children and adolescents who received methylphenidate were investigated. The MIMS Drug Classification System (2002) was used to classify drugs into their main categories. The most frequently prescribed drug categories to patients 25 years and younger together with methylphenidate were central nervous system drugs (30.6\% of the total number of prescriptions, including methylphenidate), followed by respiratory system drugs (15.4\%), antimicrobials especially penicillins (11.3\%), analgesics $(10.6 \%)$ and vitamins, tonics, minerals and electrolytes (8.8\%). A high percentage of antiepileptics were prescribed ( $17.4 \%$ of all central nervous system drugs). The three most frequently prescribed trade name products were Epanutin ${ }^{\circledast}$ (phenytoin) 100 mg capsules, Antipyn ${ }^{\circledast}$ (paracetamol, codeine phosphate and promethazine) $100 \mathrm{ml}$ syrup and Ponstel $\mathrm{S}^{\circledast}$ (mefenamic acid) $50 \mathrm{mg} / 5 \mathrm{ml}$ suspension.

\section{DISCUSSION}

The over-diagnosis of ADHD in children, the long-term safety of stimulants, the possible link between the use of stimulants and drug abuse, and the increasing diagnosis of adult ADHD are just some of the controversies that have been debated by parents, educators, marketers of alternative medicines and health professionals in South Africa (Attention Deficit Hyperactivity Disorder, 2004:2). It is recognised that the management of $A D H D$ requires a multiple modality approach, combining psychosocial interventions and medical interventions (Cantwell, 1996:983). The psychosocial interventions that have proven to be effective for children with ADHD can be classified as those psychosocial interventions that focus on the family, the school and the child. The primary psychopharmacological agents used to treat ADHD are the CNS stimulants, of which methylphenidate is probably used more than any of the other stimulants. This study focussed on the prescribing patterns of methylphenidate, since from a pharmacoepidemiological point of view, very little is known about methylphenidate and very few studies have been published on this aspect in South Africa.

Data from a medical aid administrator serving private sector medical aid patients from various areas in South Africa were obtained and all prescriptions for methylphenidate were extracted form the database and analysed. Nearly three-quarters $(73.0 \%)$ of patients were males, $79.1 \%$ of patients were 18 years or younger, and the average age of patients was 15.6 years. This finding is in line with the fact that ADHD occurs two to four times more commonly among boys than girls (Attention Deficit Hyperactivity Disorder, 2004:2). In the introduction, it was stated that international studies have yielded ADHD prevalence rates of between $1.7 \%$ and $16 \%$ (Goldman et al. 1998:1102; Markowitz et al. 2000:5). In this study, $1.8 \%$ of patients 18 years or younger, or $2.8 \%$ of patients 12 years and younger, were prescribed methylphenidate. These percentages therefore appear low in relation to the prevalence rates quoted in the international literature. However, since no statistics on the number of patients in South Africa who are using methylphenidate or who have been diagnosed with ADHD are available, it is difficult to further interpret this finding.

Although historically ADHD has been considered a disorder of children, emerging literature has indicated that ADHD is a valid, diagnosable clinical entity in adults. Prospective studies have documented the syndrome in up to $70 \%$ of older adolescents and $10 \%$ to $60 \%$ of young adults diagnosed as having ADHD in childhood. Despite the increased recognition of adult ADHD, little is known about the psychopharmacological management of this disorder in adults. Only 17 of the 115 patients in this study were 30 years or older, and the majority of these patients were males. Grown-up ADHD children with persistent ADHD symptoms into adulthood have been shown to have more psychiatric co-morbidity, school and work failures, relationship difficulties and functional impairment, than control subjects.

The dosages in which methylphenidate was prescribed in this study were all within the indicated ranges and no patient exceeded the maximum prescribed dose of $60 \mathrm{mg}$ per day (SAMF, 2003:450; MIMS, 2002:2). The use of methylphenidate in children younger than six years is debatable. The four children younger than six years in this study all received methylphenidate in a dose of $10 \mathrm{mg}$ per day, and only one of these patients was prescribed the drug on a chronic basis.

The fact that more patients were prescribed methylphenidate during the latter part of the year needs further investigation. Since methylphenidate is known 
to improve scholastic performance, it can be speculated that the drug was prescribed more often during this time of the year to help scholars prepare and write their final examinations (the academic year in South Africa is from mid-January to the end of November). This aspect can also be investigated in a qualitative study.

Known adverse effects of methylphenidate are weight loss and growth retardation, especially in children receiving doses exceeding $30 \mathrm{mg}$ per day for prolonged periods (SAMF, 2003:450). Only three children received methylphenidate in doses exceeding $30 \mathrm{mg}$ per day and only one of them received more than one prescription during the year. Since the height and weight of patients were not included in the database, this aspect could also not be investigated further.

\section{CONCLUSION}

The pharmacotherapy of ADHD is under-researched in South Africa. Although sales figures are available for different drugs, no comprehensive South African database exists from which methylphenidate prescribing patterns, especially over extensive time periods, can be studied. Also, no computerised medication records are available for the state or public sector, and very few private sector databases contain comprehensive diagnostic information linking specific medicine items to a specific diagnosis. Although the number of patients in this study was relatively small and not representative of the South African population as a whole, it nonetheless attempted to add to the available literature on methylphenidate prescribing in South Africa.

The limitations of retrospective drug utilisation reviews are furthermore recognised. The analysis occurred after the dispensing process so that no corrective action could be taken in case of prescribing errors. Databases also lack important and valuable patient variables, such as height, body weight and various lifestyle variables that could assist in interpreting prescribing patterns. In this study, there were no variables that could be analysed to establish whether methylphenidate therapy was successful or not. It is also difficult to investigate repeat prescriptions and drug holidays, since data for only a year was analysed and it was not known when drug therapy with methylphenidate was initiated.

The results of this study were generally in agreement with two previous South African studies conducted on different prescription databases in 1996 and 2002 on methylphenidate. Further studies are recommended, especially into the quality of life of patients before and after receiving methylphenidate. The impact of methylphenidate on the academic performance of young patients should also be quantified. Finally, the dosages and duration of treatment with methylphenidate also warrant further investigation. It is recommended that quantitative studies on methylphenidate prescribing be combined with qualitative studies to obtain a better insight into the clinical response and effectiveness of this important drug.

\section{ACKNOWLEDGEMENTS}

- The South African medical aid administrator who provided the data for this study.

- Mrs Samantha Venter for proofreading the manuscript.

- The Research Committee of the Nelson Mandela Metropolitan University for financial support to conduct this study.

\section{REFERENCES}

ANATOMICAL THERAPEUTIC CHEMICAL (ATC) CLASSIFICATION INDEX WITH DEFINED DAILY DOSES (DDDs) 2001: Oslo: WHO Collaborating Centre for Drug Statistics Methodology. ATTENTION DEFICIT HYPERACTIVITY DISORDER 2004: Cramerview, South Africa: Insight Medicine Management on behalf of the Alpha Pharm Continuing Education Programme. Module 1 (February): 1-20.

BERRY, CA; SHAYWITZ, SE \& SHAYWITZ, BA 1985: Girls with attention deficit disorder: A silent minority? A report on behavioural and cognitive characteristics. Pediatrics, 76(5):801-809.

BNF - See British National Formulary.

BAUMGAERTEL, A; WOLRAICH, ML \& DIETRICH, M 1995: Comparison of diagnostic criteria for attention deficit disorders in a German elementary school sample. Journal of the American Academy of Child and Adolescent Psychiatry, 34:629-638. BRITISH NATIONAL FORMULARY 2003: Edited by Mehta, DK. London: British Medical Association and the Royal Pharmaceutical Society of Great Britain.

CANTWELL, DP 1996: Attention deficit disorder: A review of the past 10 years. Journal of the American Academy of Child and Adolescent Psychiatry, 35(8):978-987.

CENTRAL STATISTICAL SERVICE 1996: 1995 October Household Survey. Pretoria: Government Printers. 
CRUTCHLEY, A \& TEMLETT, JA 1999: Methylphenidate (Ritalin) use and abuse. South African Medical Journal, 89(10):10761079.

ELIA, J; AMBROSINI, PJ \& RAPOPORT, JL 1999: Treatment of attention-deficit-hyperactivity disorder. New England Journal of Medicine, 340:780-788.

GOLDMAN, LS; GENEL, M; BEZMAN, RJ \& SLANETZ PJ 1998: Diagnosis and treatment of attention-deficit/hyperactivity disorder in children and adolescents. Journal of the American Medical Association, 279(14):1100-1107.

MARKOWITZ, JS \& DEVANE, CL 2000: Attention-Deficit Hyperactivity Disorder and the rise in methylphenidate use. US Pharmacist (Supplement), November:3-12.

MIMS - See MIMS Medical Specialities.

MIMS MEDICAL SPECIALITIES 2002: Edited by Snyman, JR. Pretoria: Times Media. June, 42(6).

PRACTICE PARAMETER FOR THE USE OF STIMULANT MEDICATIONS IN THE TREATMENT OF CHILDREN, ADOLESCENTS, AND ADULTS 2002: Journal of the American Academy of Child and Adolescent Psychiatry, 41(2), Supplement: 26S-49S.

ROBISON, LM; SCLAR, DA; SKAER, TL \& GALIN, RS 1999: National trends in the prevalence of attention-deficit/hyperactivity disorder and the prescribing of methylphenidate among schoolage children: 1990-1995. Clinical Pediatrics, 38(4):209-217.

SAMF - See South African Medicines Formulary.

SOUTH AFRICAN MEDICINES FORMULARY; $6^{\text {th }}$ edition 2003: Edited by Gibbon, CJ. Cape Town: Health and Medical Publishing Group, South African Medical Association.

SPENCER, T 2003: The long-term safety of stimulant treatment. Medscape Psychiatry \& Mental Health, 8(2). http:// www.medscape.com/viewarticle/458811. (Accessed: 10 June 2005).

SPENCER, T; BIEDERMAN, J; HARDING, M; O'DONNELL, D; FARAONE, S \& WILENS T 1996: Growth deficits in ADHD children revisited: Evidence for disorder-associated growth delays? Journal of American Child and Adolescent Psychiatry, 35:14601469.

TRUTER, I 2004: Methylphenidate (Ritalin $\left.{ }^{\circledR}\right)$ : Prescribing patterns in a South African primary care patient population. Journal of Child and Adolescent Mental Health, 15(2):96.

TRUTER, I \& KOTZE, TJ VAN W 2000: Prescribing patterns of methylphenidate in a South African patient population. Pharmacoepidemiology and Drug Safety, 9(Supplement 1):S42-S43.

WICK, JY 1993: Use of psychoactive medications in children and adolescents. American Pharmacist, NS33(1):51-58. 